\title{
De psychiatrie van het algemene ziekenhuis
}

Citation for published version (APA):

Verhey, F. H. M. (1986). De psychiatrie van het algemene ziekenhuis. Maastricht University. https://doi.org/10.26481/spe.19860620fv

Document status and date:

Published: 20/06/1986

DOI:

10.26481/spe.19860620fv

Document Version:

Publisher's PDF, also known as Version of record

\section{Please check the document version of this publication:}

- A submitted manuscript is the version of the article upon submission and before peer-review. There can be important differences between the submitted version and the official published version of record.

People interested in the research are advised to contact the author for the final version of the publication, or visit the DOI to the publisher's website.

- The final author version and the galley proof are versions of the publication after peer review.

- The final published version features the final layout of the paper including the volume, issue and page numbers.

Link to publication

\footnotetext{
General rights rights.

- You may freely distribute the URL identifying the publication in the public portal. please follow below link for the End User Agreement:

www.umlib.nl/taverne-license

Take down policy

If you believe that this document breaches copyright please contact us at:

repository@maastrichtuniversity.nl

providing details and we will investigate your claim.
}

Copyright and moral rights for the publications made accessible in the public portal are retained by the authors and/or other copyright owners and it is a condition of accessing publications that users recognise and abide by the legal requirements associated with these

- Users may download and print one copy of any publication from the public portal for the purpose of private study or research.

- You may not further distribute the material or use it for any profit-making activity or commercial gain

If the publication is distributed under the terms of Article $25 \mathrm{fa}$ of the Dutch Copyright Act, indicated by the "Taverne" license above, 


\section{DE PSYCHIATRIE VAN HET \\ ALGEMENE \\ ZIEKENHUIS}

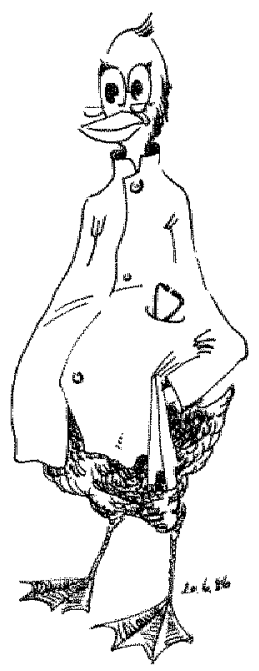


Uitgave: Afdeling Kinische Psychiatrie, Academisch Ziekenhuis Maastricht

Drukkerij: EBU

Copyright: Dr. F. Verhey

ISBN Mr. $90-9001324-5$ 


\title{
DE PSYCHIATRIE VAN HET ALGEMENE ZIEKENHUIS
}

\author{
Rede \\ uitgesproken bij de aanvaarding \\ van het ambt van Hoogleraar \\ in de Klinische Psychiatrie \\ aan de Rijksuniversiteit Limburg \\ op Vrijdag 20 juni 1986
}

\author{
door \\ Dr. F.H.M. Verhey.
}

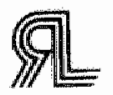

Rijksuniversiteit Limburg 


daar niet mee eens. Alles wat ik weet heb ik geleerd wit ervaringen, die nu verleden tijd zijn. Juist met het oog op de verdere ontwikkeling van die verhouding tussen de psychiatrie en de geneeskunde moge ik U uitnodigen voor een terugblik op de merkwaardige relatie van deze partners. Dat geldt in het bijzonder wanneer deze partners ook nog "voordeurdelers" $z$ ijn zoals het geval is met de psychiatrische afdeling van het algemene ziekenhuis.

\section{DE ZINNELOZEN EN DE KRANKZINNIGEN}

De psychiatrie van het algemene ziekenhuis heeft geen eigen historie. Ze is vervlochten met die van de psychiatrie als geheel en vertoont bovendien alle kenmerken van de a mbivalente relatie tussen de psychiatrie en de geneeskunde. Natuurlijk hebben wijze mannen al vanaf de vroege oudheid zeer opmerkelijke dingen gezegd over allerlei ook nu nog herkenbare psychiatrische beelden. Voor een algemeen beleid ten aanzien van de zorg voor de "zinnelozen" of "krankzinnigen" (deze termen geven al een geweldige evolutie weer) heeft dit tot een goede honderdvijftig jaar geleden weinig opgeleverd. Deze geschiedenis laat een wat grillige evolutie zien, die vanuit de mensonwaardige kotten van de middeleeuwse dollhuizen tot op de dag van vandaag gekenmerkt wordt door wisselvalligheid van inzicht, enerzijds in de identiteit van de psychiatrie zelf, anderzijds in de aard van de relatie tussen deze psychiatrie en de overige niet psychiatrische, meer "lichamelijke" specialismen binnen de algemene geneeskunde. Bovendien blijkt dat deze wisselvalligheid soms bepaald wordt door zeer praktische en af en toe opportunistische (economische of politieke) belangen samenhangend met konkrete gebeurtenissen, tijdgeest en instituutbeleid. Systematische bemoeienis van de geneeskunde met de psychiatrische gezond heidszorg is in Nederland, en daarbuiten, nauwelijks anderhalve eeuw oud.

Frederik Willem IV, de latere Koning Willem I van het Koninkrijk der Verenigde Nederlanden, had in 1805 tijdens zijn verbanninguit de Nederlanden, in het geseculariseerde Bisdom Fulda het naar hem genoende "Wilhelmhospital" gesticht met de uitdrukkelijke opdracht hierin ook geesteszieken op te nemen. Zijn, mede hierdoor duidelijk gebleken, engagement met het destijds treurige lot van deze "zinnelozen" leidde ertoe dat na zijn terugkeer in Nederland een begin gemaakt werd met een wettelijke 
regeling van de krankzinnigenzorg als onderdeel van een door de staat gereguleerde gezondheidszorg in het algemeen.

Daartoe schreven de Amsterdamse "Provinciale Commissieën van Geneeskundig Onderzoek en Toevoorzigt" per 31 Mei 1821 een wedstrijd uit. De opdracht was, met een perspectief op de huidige ziekenhuispsychiatrie en de leer der psychosomatosen, belangwekkend en actueel:

"Welke psychische en physieke middelen ter genezing van geestesziekten werden in de laatste jaren bekend; welke hebben in de praktijk bewezen dat zij het lot van deze ongelukkigen verlichten of de ziekte genezen; welke invloed hebben deze gehad op ziekten die, ofschoon niet rechtstreeks samenhangend met geestesziekten, toch af en toe daarmee gelijktijdig optreden; wat is de invloed van deze ziekten op de psychische toestand en welke invloed heeft ongekeerd de psychische toestand van de geesteszieke op deze ziekten?"

Onderdeel van de wedstrijd, die gewonnen werd door overigens de enige inschrijver - de Gentenaar Joseph Guislain, was ook de bestudering van een aantal met name genoemde psychiatrische instituten in Europa waaronder drie psychiatrische afdelingen van algemene ziekenhuizen in Parijs, Wenen en Berlijn. De andere waren wat men nu zou noemen kategorale algemene psychiatrische ziekenhuizen: Bethlem en St. Luke's Hospital in Londen, Sonnenstein ten Zuiden var Dresden en Charenton in Parijs. Deze instituten werden beschouwd als voorbeelden ter bestudering met het oog op de gewenste verdere ontwikkeling. Dus ook in deze periode is het duidelijk dat de klinische psychiatrie, voor zover men daar in die periode van kan spreken, uitgeoefend werd enerzijds in daartoe specifiek ingerichte instituten, anderzijds in afdelingen als onderdeel van algemene ziekenhuizen. In Nederland waren kennelijk geen voorzieningen voorhanden die als voorbeeldig aangemerkt konden worden.

De door Lodelijk de XIV gestichtte "algernene zickenthuzen van Pariss" de Salpetriere en Bicetre hadden van neet a a an cen belangrijke tak in de behandeling wan psychiatrische pattenten. In de Salpetrieve werden vrouwelijke en in Bicetre mannelijke krankinnigen verpleagd. Historigche namen als die van Pinel con Charcot zijn das roorgoed an werbonden. Ook signund freud, die bij Charcot in de Salpetriete zijn dissertatie over de kinderverlamming 
bewerke gal hier, zieh creatgef verbazend ower we wonderbaarlijke dingen die zijn leermeester Charcot met behulp san hypnose verrichte bil hysterische conversie-palienten, vorm an zijn eerste concepten omirent de psychoanalyse.

Het is - mede in het perspectief op de Mastrichtse Paaz-historie -interessant wast te stellen dat de bestuurders van de Salpetriere en Hictre in 1910 bestoten om de psychiatrische afdelingen; na rum en eew bestan te hebben, te sluiten om ze enkele decenneen later weer te heropenen, watbif deze nieuwe beslising werd gepresenteerd als cen origineel en wooruitstrevend imitiatief gehel in harmonie met de vooruitgang van de geneeskunde. Steeds weer bitiken bestuurders in de verleting te komen om de psychiatrische voordeurdeler de deur wit te zetten om zich pas daarna op hel droeve gemis te bezinnen.

Het "Algemeine Krankenthaus" in Wenen bevatte van oudsher een psychiatrische afdeling, die an het einde van de 19 de eeuw onder Meynert verheven werd tot Universiteitskliniek.

In Berlijn zien we dat het in 1710 gebouwde algemene ziekenhuis "die Charite" genaamd in 1798 verplicht is on een groot aantal krankzinnigen op te nemen nadat het platselijke gesticht door brand werd vernield. Deze afdeling werd lange lijd beschouwd als een der meest op de voorgrond tredende psychiatrische centra van Duitsiand.

Orschoon de eerste formele psychiatrische afdeling in de Verenigde Staten in 1902 geopend werd in thet Albany (N.Y.) Medical Center, vertelt de geschiedenis dat reeds in 1755 in het Pennsylvania Hospital bedden werden gereserweerd voor "the cure and treatment of lunatics". Toch is het pas na de tweede Wereldoorlog dat in de Verenigde Staten de trend om psychiatrische patienten in algemene ziekenhuizen te behandelen op grote schaal doorzet.

\section{NEDERLAND}

Voorzover ik kon nagaan is er in Nederland voor het eerst sprake van een psychiatrische afdeling in een algemeen ziekenhuis in 1635 en wel in het Buitengasthuis te Amsterdam omdat (in dit geval) het aantal beschikbare plaatsen in het plaatselijke "dolhuis" ontoereikend bleek. De psychiatrische afdeling van het Buitengasthuis werd honder jaar later uitgebreid tot 164 bedden.

Het Amsterdamse "dolhuis" werd gesticht in 1562 en de eerste patient werd opgenomen op 20 October 1567 . Het blijkt te gaan om een Rooms Katholieke priester. Elbert Huyck, en vervolger van de Lutheranen. Hij verbleef daar tot zign dood op 30 mei 1597 . Het psychatrisch ziekenthuis als ballingsoord voor dissidenten is duidelijh niet alleen wan deze tijd. 
Door éen "casus" wat witvoeriger te bespreken is het vaak mogelijk een aantal meer algemene wartheden woe te lichten. De geschedenis van de krankzinnigenzorg te Marastricht gaf mil daartoe de gelegenteid.

De eerste "harde" gegevens omtrente krankzinigenzorg in Mastricht komen uit de financied-economische hoek. Een resolute van de gemeenteraad van Maastricht van 1584 besloot om een "zinneloze" op kosten van de overhed onder te brengen bij de Fallezusters of Fejlansters. Deze vestigden zich in 1470 met toestemming van Jan van Horne, Prins-Bisschop wan Luik in Maastricht, in een huis genaamd "de poort van pietershe"m" en gelegen achter de oude wal. Ze hadden de uitdrukkelike verplichting op zich genomen de zieken te verzorgen. lets vroeger dan de Faliezusters - in 1438 - had zich ook een gemeenschap van lekebroeders, de zogenaande Callebroeders, ook wel Lollarden of Alexianen genoemd, in Maastricht gevestigd. Ze kregen van stadswege een terrein aan de Brusselsestraat om er een kerk en een kfooster te bouwen. Ook voor hen gold als woorwarde wan vestiging: het verplegen van zieken.

Het stadsbestuur haalde dus oprettelik deze orden nat Maastricht en verleende bepaalde faciliteiten, opdat ze zich zouder wijden an de ziekenverpleging. Wat de zorg voor de krankzinnigen betreft, bemoeide het stadsbestuur zich slechts met die "zinnelozen" die niet op eigen kosten hetzij thuis, hetzij in een van die genoemde kloosters werden verpleegd. Het is trouwens interessant te lezen, dat in deze tigd het aantal thuis verpleegden veel groter was dan het aanal "intramural" opgenomen zinnelozen. Thuis- en gexinsverpleging speeden vootheen ook in Maastricht een veel belangrijkere rol. Met de toenemende ontwikeling en organisatic van de mathschappij is de tollerantie afgenomen.

De gelden kwamen niet rechtstreeks uit de gemeentekas, mar van de zogenaamde Armentafel van de Heilige Geest, een instelling, reeds daterend uit de $\$ 2$ de ectuw. Aanvankelijk werden de bestuurders, "heyligegeyst-meysteren" genoemd, gekozen door de ambachten. Later beheerde de stad de goederen van deze armentafel en verhoogde haar inkomsten met de boeten, die aan de burgers in sommige gevallen werden opgelegd. 
Op I December 1642 keurde het stadsbestuur een overeenkomst goed tussen de Armentafel en de Cellebroeders; waarbij deze laatsten zich bereid verklaarden behoefine krankzinnigen tegen betaling van een bepaald bedrag te verplegen. Na die datum werden geen geesteszieken meer geplaatst bij de faliezusters, die, met toestemming van de magistraat hun regel veranderd hadden en niet langer de ziekenverpleging tot hun taak rekenden.

In 1673 vestigden zich hier in de Heksenhoek de Grauwe Zusters of Grauwzusters. In de overeenkomst tussen het Gemeentebestuur en de Grauwzusters lezen we: "ende te doen hunne functie omtrent de siecken zonder distinctie van contagieuse oft andere sieckte "soo ende gelijck sij in de stadt van Hasselt ende andere plaatsen sijn doende". Uit de overeenkomst blijkt voorts dat de zusters zich ook verplichtten tot de verzorging van krankzinnigen.

Telkens weer blijkt dat het stadsbestuwr zich grote zorgen maakte over de hoge kosten (in het begin van de $18 \mathrm{e}$ eeuw 250 gulden 's jaars) van de intramurale krankzinnigenzorg. Op grond hiervan werden (ook toen al) extramuralisatieplannen gemaakt en uitgevoerd. Men plaatste enkele krankzinnigen tegen lagere vergoeding bij particulieren en er werd in 1753 contact opgenomen met Geel in België, in die tijd reeds een centrum voor gezinsverpleging. De kosten te Geel bedroegen 140 gulder per jaar, hetgeen uiteraard een aanmerkelijk verschil uitmaakte met de 250 gulden bij de Cellebroeders te Maastricht. In Mei van dat jaar werden de zinnelozen bij de Cellebroeders weggenomen en naar Geel getransporteerd. Gezien de triomfantelijke toon, die wij kunnen lezen in de betreffende besluiten was men kennelijk verheugd over het behaalde voordeel. Dat de oplossing toch niet bevredigend was, blijkt uit het feit dat de Maastrichtse krankzinnigen reeds een jaar later weer uit Geel werden teruggehaald ("wrachtkosten" 1/2 rijksdaalder per man). Men achtte het "zowel voor de zinnelozen zelf als voor de stedelijke financièn" het beste ze te plaatsen bij een zekere Gerard Delnoz, een particulier, die in zijn huis in de Maastrichter Grachtstraat reeds krankzinnigen verpleegde.

\section{PARTICULIERE ZORG $(1754-1847)$}

Van deze tijd (begin A pril 1754) dateert de verzorging van krankzinnigen op enigszins grotere schaal door particu- 
lieren "op eigen risico". Overigens bleek men van overheids wege niet erg tevreden met de kwaliteit van de zorg. Visitaties en vermaningen hadden geen resultaat.

Tegen half $\mathrm{Mei} 1767$ werden de zinnelozen overgeplaatst naar het huis van een zekere Augustinus La Rocque in de St. Antoniusstraat. Deze La Rocque werd enkele jaren later. beschuldigd van bepaalde praktijken, opgesloten in de gevangenis van het Oud-Stadhuis en de verpleging werd toevertrouwd aan Gerard Gulikers. Deze toestand zou in principe voortduren to 1847 . Wel traden er. mede onder invloed van de Franse wetgeving, na de inlijving bij de Franse republiek in 1794 enige organisatorische veranderingen op. Een zekere Joannes Didden oppasser in het zinnelooshuis van genoemde Gulikers en tegelijkertijd cipier in de gevangenis (de combinatie is veelzeggend) werd in 1797 door zijn Franse vrienden wegens verleende diensten tot "entrepreneur" benoemd wan het overigens nog steeds particuliere tehuis, dat nu gevestigd was in het (vomrmalige) klooster in de Looyerstraat, waaruit de Grauwasters, onder protest, verwijderd werden. Ook de Armentafel van de H. Geest was inmiddels opgeheven en de fondsen werden onder beheer gesteld van "Le Conseil d'Administration des Fondations Pieuses" later aangeduid als "Hospices Civiles". Na het vertrek van de transen bleef dit licham bestaan nu onder de naam van "Kollegie van Regenten van den Algemeenen Armen" de voorloper van het huidige Burgerijk Armbestuur.

Tot dusver was er slechts sprake van dolhuizen, war krankzinnigen of zinnelozen opgesloten werden. Uit diverse geschriften blijkt dat er van enige diagnostick of behandeling nauwelijks sprake was. In feite ging het om een gemengde populatie van landlopers, criminelen, prostituees, zwakzinnigen en "echte" krankzinnigen.

Naar alle waarschijnlijk heid is de term "psychiatrie" eerst in 1816 door Johann Christian Reil ingevoerd. De psychiatrische zorg had nauwelijks iets met geneeskunde te maken. Het zeldzame bezoek wan de stadsgeneesheer betrof slechts een contrôle in verband met de financièle bijdrage van de overheid. Trouwens zieken van geest genezen was ook niet het doel van het zinnelooshuis, het was slechts een plaats, war ze opgesloten werden.

Nog in 1845 werd de lowstand in het particultere huis woor gimelo zen in Mastrich als abominabel beschreven in een rappon van Gedeputeerde Staten: Er zijn nog altije kribben in gebruik dic tot slapplats dienen voor wee personen. De luch in het daguerbliff is ondraglijk. Er is totaal geen toezcht. Mannen en vrouwen dwatan door het gehele "bouwvallige en te nawse" gebouw. Bedlinntw ontbreekt geheel en al, dekens en strozakken werkeren in versteren. 


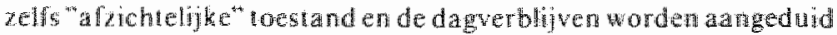
als "hokken". Overigers blijk zonneklara un een rapport van de inspecters Schroeder ven der Kolk en Fenh in 1848 dat deze

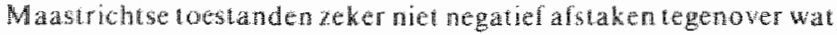
landelijk werd vasugesteld.

\section{KRANKZINNIGENZORG ONDER TOEZICHTVAN DE OWERHEID}

Toch $\mathrm{k}$ wamen vanaf deze periode de ontwikkelingen in een stroomversnelling, thier in Nederland niet in de laatste plaats door de actieve bemoeienissen van de reeds genoemde Koning Willem I. Van grote betekenis is ook geweest een rede uitgesproken ter gelegenheid van de rectoraatsoverdracht aan de Universiteit te Utrecht, door prof. J.L.C. Schroeder van der Kolk. Deze rede was de directe aanleiding tot de voorbereiding van de wet van 29 Mei 1841 , die de zorg voor de krankzinnigen onder staatstoezicht stelde. Na zeer veel politiek get wist tussen Provincie, Gemeente en Burgerlijk Armbestuur deelde

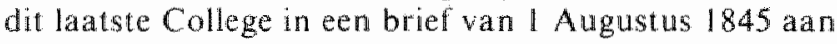
Burgemeester en Schepenen van Maastricht mee dat zij voornemens waren op het terrein van het klooster Calwarieberg annex aan het daar reeds onder haar beheer aanwezige ziekengasthuis en bejaardenhuis een gesticht woor behoeftige krankzinnigen in te richten.

De voorwasden die opgenomen zijn in lhet betreffende Koninklijk Besluit wan 23 April 1846 zija opmerkelik: hel gesticht moet geheel afronderlijk wordon gehouden van het amgrenzende gasthuis; de bijzondere oppassers voor de krankzinnigen mogen in geen geval in atanraking komen met die van het gasthuis; well dient de grote tuin wan het gasthuis onderhouden te worder door de arbeid van de krankzinnigen. Het nienwe gesticht werd aldus geopend op $1 \mathrm{Me}$ 1847 .

Het was in dit zelfde instituut dat ik, precies 100 jaar later, in 1947 als coassistent mijn intrede deed in de wereld van de psychiatrie.

Wanneer men de psychiatrie van deze 100 jaar overziet dan lijkt het niet overdreven wamneer men stelt dat de psychiatrie als geneeskundig specialisme in dexe honderd jaar geboren is en, ofschoon nog niet echt volwassen, toch gevorderd is tot een stadium dat, gezien de onstuimige kenmerken van de ontwikkeling in de laatste 40 jaren, vergeleken zou kunnen worden met een puberteit. 
Terug naar de geschiedenis. Ofschoon, zoals wij gezien hebben de patienten en de oppassers van de inrichting volledig gescheiden dienden te worden van die van het gasthuis bleek dit niet te gelden ten aanzien van de medische verzorging in engere zin. Trouwens ook het gasthuis bleek in die tijd slechts te beschikken over één enkele arts, de Heer Beckers, "doctor in de drie geneeskundige vakken". De band met de algemene geneeskunde groeide geleidelijk via een gemeenschappelijke medicus. Hij had de verplichting om het gesticht eenmaal daags te bezoeken en in buitengewone gevallen "zelfs een tweede bezoek daags aan de daarin verpleegd wordende lijders te geven". Hij kreeg voor deze taak een honorarium van honderd gulden per jaar.

Tot 1936 bleef deze toestand gehandhaafd, al werd het honorarium verhoogd. Van een specialistische psychiatrische behandeling was er dus nog geen sprake.

Men moet daarbij bedenken dat de eerste Nederandse Hoogloratr in de psychatrie en de neurologie Cornelis Winkler pas in 1893 als zodang in Utrecht benoend werd cofschoon hij deze vakken al sinds 1885 als lector aan de medische studerten docerde). In dat jaar werd hij samen met Gerbrandus Jelgersma lid var de Vereniging van Psychiatrie, de oudste specialisterwerenging van Nederland. waarvan de naam op hun beider voorstel in 1895 werd veranderd in Vereniging voor psychiatrie on newrologie.

Het specialisme psychiatrie en newrologie zell werd pas enkele tientallen jaren later ingesteld. In ieder geval blijkt dat de psychiatrie haar intrede doet in de officiële geneeskunde hand in hand met de neurologie (sommige neurologen spreken van een tijdelijke mesailliance). Het is dus niet vreemd dat pas in 1936 de eerste psychiater-neuroloog, de Heer J.G.Y. de Jong in het Maastrichtse ziekenhuis werd aangesteld. Deze zenuwarts had naast de zorg over een neurologische afdeling ook specialistische bemoeienis met wat geleidelijk tol "de psychatrische afdeling (P.A.) van het ziekenhuis Calvarieberg" was geevolueerd. Hij werd in 1941 opgevolgd door Dr. Piet Mesker, die dus in 1947 mijn eerste leermeester in de psychiatrie en neurologie werd. Het is a an de bijna magisch-creatieve en zeer geëngageerde wijze waarop hij psychiatric kon presenteren te danken dat ik vanaf die tijd vastbesloten was dit specialisme te kiezen.

Uit de geschiedenis tot dusver blijkt hoe in Maastricht na 
eeuwen wan dol huis en thuisverpleging, de psychatrie als medisch specialisme tot ontwikkeling kwam in een afdeling van het algemene zekenhuis, waar de klinische psychiatrie op kleinschalige wijze en naw verbonden met de reurologie, mar wel in gescheiden afdelingen. werd uitgeoefend.

\section{RECENTE GESCHIEDENIS.}

IN MONTE CALVARIAE IN MENTE SALVATUR. EEN PAAZ VOOR HET ZIEKENHUIS.

Aan deze alliantie kwam een einde toen het Burgerlijk Armbestuur besloot tot oprichting van het ziekenhuis St. Annadal dat, ondergebracht in een aparte stichting, geopend werd in 1950. Beslist werd dat hierbij de psychiatrische afdeling (P.A.) niet mee over zou gaan, maar met het tehuis voor ouden van dagen (her Godshuis) als psychiatrische inrichting (P.I.) zou achterblijven op de terreinen van Calvarieberg. "In Monte Calvariae In Mente Salvatur" stond op de insignes yan de verpleegkundigen.

Na een scheiding van net tien jaar kwam het weer tot een hereniging. In 1960 werd ik, met twee halftime contracten, in beide instituten aangesteld. Tevens werd in dat zelfde jaar besloten om in het ziekenhuis een eigen, van de neurologie gescheiden, psychiatrische afdeling in het leven te roepen. Na nog eens tien jaren wan improvisatie kreeg deze afdeling concrete gestalte bij het gereed komen van de nieuwbouw in 1970 . Deze psychiatrische afdeling kreeg in $198 \mathrm{I}$ haar wettelijke, zogenaamde PAAZ-erkenning. De kwetsbaarheid van de relatie tussen ziekenhuis en psychiatrie moge blijken uit het feit, dat de existentie van de psychiatrische afdeling in deze periode tweemaal op het spel gezet werd, eenmaal door de bestuurders bij de komst van de academische cardiologie, eenmaal door het departement als prijs voor de hartchirurgie. Door gezond verstand bleef de relatie beide keren behouden. Ook aan de kant van de psychiatrische inrichting was men in toenemende mate niet tevreden met de scheiding. De personele unie van een psychiater was een cerste stap. Toen in de zestiger ja ren de nieu w bou w plannen voor een psychiatrisch ziekenhuis gestalte kregen werd eerst gedacht aan vestiging op het Annadal terrein en toen er sprake was van een nieuw academisch ziekenhuis op het 
terrein tussen Heer en Bemelen werd beslotem om daar het nieuwe psychiar rische ziekenhuis neer te zetten als eerste onderdeel van het toekomstige A cademisch Ziekenhuis Maastricht. Zo kwam het PMS Vijverdal tot stand. Maar de plannen veranderden, het nieuwe $A Z M$ verhuisde (eerst op papier en later in werkelijkheid) naar Randwyck en de psychiatrie lag toch weer alleen.

\section{EINDE VAN HET ALGEMEEN PSYCHIATRISCH ZIEKENHUIS?}

De zinnigheid van het algemeen psychiatrisch ziekenhuis is volop in discussie. Inmiddels is deze discussie zover geèvolueerd dat voor de verschillende daarbinnen samenwonende bestanden gedacht wordt aan divergente oplossingen. Een kleine groep patiënten zal blijvende verpleging nodig hebben. Een veel groter deel van de $A P Z$ bewoners lijkt in aanmerking te komen voor een aangepaste extramuralisatie en rehabilitatie. Uit de zorg waarmee dit proces omringd wordt kan blijken dat men de lessen uit de geschiedenis (zowel de oude als de recente) geleerd heeft.

Het ligt in de lijn van de verwachtingen dat de typisch klinische afdelingen in de toekomst meer aansluiting zullen zoeken bij het nieuwe academisch ziekenhuis, een ontwikkeling die door mij van harte onderschreven wordt.

\section{TWEE PARTNERS}

De psychiatrie is thans een door de Specialisten Registratie Commissie erkend medisch specialisme. Wat heeft de band met de algemene geneesk unde nu voor de psychiat rie opgeleverd?

Op de eerste plaats dient men zich te realiseren dat de band met de traditionele geneeskunde op een andere manier tot stand kwam dan het geval is met de meeste andere specialismen.

Hiervoor heb ik al even gememoreerd dat de eerste geneesheer die alhier vaste bemoeienis met de psychiatrie kreeg, Beckers, doctor in "de drie geneesk undige vakken" was. Daarmee wordt bedoeld "de genees-, heel., en verloskunde". De officiële geneeskunde was, onder staatstoezicht, ook pas sinds het begin van de 19 de eeuw tof 
stand gekomen uit een samenraapsel van "kruidendokters" die de geneeskunde bedreven, waruit zich de "interne vakken" ontwikkeld hebben, "chirurgijnen" die de kost vooral ook moesten verdienen als barbier en tenslotte verlos kundigen ook wel vroedmeesters of vroedvrouwen genoemd.

De psychiatrie hoorde daar niet bij, zij was "van mindere afkomst". Zinnelozen werden niet behandeld, maar samen mel andere "asociale" personen opgesloten en door oppassers in leven gehouden.

Zoals we uit de vooralgaande historie van de praepsychiatrie al konden leren, werden psychische stoornissen veeleer gezien als samenhangend met immoraliteit, dan als ziekten. Die schuldvraag is de psychiatrie nooit helemaal kwijt geraakt. Toen men tot het inzicht $\mathrm{kwam}$ dat "zinnelozen" eigenlijk "krankzinnigen" waren, dat ze als zieken beschouwd moesten worden, was dit een vaststelling geheel in biologische zin. Volledig in overeenstermming met de medische traditie van de 19 eeuw ging men ervan uit dat psychische stoornissen uitsluitend berustten op hersenziekten. Toen rond en na de eeuwwisseling daar nieuwe ontwikkelingspsychologische dimensies aan toegevoegd werden, dook ook al snel dat schuldidee weer op. Niu waren het niet de patienten maar de opvoeders, de ouders, die schuld waren aan het disfunctioneren van hun kinderen. Weer later, na de tweede wereldoorlog, bij het opkomen van de sociale psychiatrie werd de beschuldigende vinger gericht op de hele maatschappij. De antipsychiatrie was daarvan een uitvloeised. Als echt inzicht in de oorzaken ontbreekt duikt al gauw de schuldvraag op. Aetiologie was en is een zwak punt in de psychiatrie.

Als men spreekt over consultatieve activiteiten van de psychiater op een der andere afdelingen van het ziekenhuis dan noemt men dit "liaesonpsychiatrie". Wie heeft ooit horen spreken wan liaeson-chirurgie, liaeson-neurologie of iets dergelijks? Er is sprake van een relatie, een verbinding tussen twee verschillende denk-en werkwerelden. Een poging om "andersdenkenden" samen aan een tafel te krijgen. De Amerikaanse psychiater, C.P. Kimbal. spreekt op een congres over "general hospital psychiatry in 1983 over "oecumene psychiatrie". Daar lijkt, ook in de prakuijk, vaak veel voor te pleiten. Het gaat soms om. conceptuele verschillen in benadering. Maar daar komen we nog op terug. 
Toch heeft de psychiatrie uit het contact met de geneeskunde in ieder geval het ziektekundig denken en handelen overgenomen en bewaard. Dat wil zeggen de opvatting dat psychische stoornissen gezien moeten worden als ziekten, met symptomen, die geobserveerd en geregistreerd dienen te worden met een daarop volgend klassificatiesysteem dat tot een diagnose en een daarmee samenhangende behandeling leidt. Deze wijze van "nosologisch" denken, soms (ten onrechte) aangeduid als "het medisch model" werd (en wordt) binnen de psychiatrie nog al eens bediscussieerd en verworpen, maar vooral de laatste jaren is er sprake van een meer algemene aanvaarding van deze in de geneeskunde algemeen gangbare methodiek. De grondslag voor deze systematische psychopathologie is gelegd in de vorige eeuw door klassieke Duitse psychiaters. Toch bleken psychiaters het tot voor kort maar zelden eens te zijn over de diagnose van hun patiënten. In het anecdotische wlak was dat all langer bekend. Onderzoek in de laatste decenniën bracht in getallen aan het licht hoe ontstellend deze discordantie was. In de laatste tien jaren is binnen de psychiatrie aan deze systematiek nieuwe vorm gegeven door het invoeren van gestandaardiseerde onderzoekmethodes zoals bijvoorbeeld de "Present State Examination" en moderne klassificatiesystemen als de zogenaamde DSM III (Diagnostic and Statistical Manual of Mental Disorders, in derde editie uitgegeven door de American Psychiatric Association).

\section{EEN MESAILLIANCE?}

Een geheel ander gebied waarin de geneeskunde belangrijke bijdragen aan de psychiatrie heeft geleverd (en omgekeerd) komt voort uit de nauwe relatie die oorspronkelijk bestond met de neurologie. Medici als Bonhoeffer en Babinski, om er maar eens twee te noemen, hebben vanuit hun kennis van zowel de menselijke hersenen alsook van het menselijk gedrag zeer belangrijke beelden als de symptomatische psychosen (ook wel exogene reactietypen genoemd) of de agnosieèn beschreven in relatie tot bepaalde hersenstoornissen. Het hele terrein van wat tegenwoordig wordt aangeduid als "orga nische psychosyndromen" verwijst naar een rechtstreekse en herkenbare relatie tussen bepaalde gedragsstoornissen en daarmee 
samenhangende hersenfunctiestoornissen.

Het is overigens heel opmerkelijk dat het tegenwoordig steeds meer erop begint telijken, dat dit gebied (hersenen en gedrag) steeds minder door medici en steeds meer door psychologen en vooral door psychofysiologen wordt onderzocht en gekend. Een van de bellemmeringen voor een wetenschappelijke psychiatrie bestaat daarin dat men gedwongen is zich steeds bezig te houden met psychopathologie, waar de kennis van de psychofysiologie ontbreekt. Wij moeten behandelen wat afwijkend is zonder voldoende inzicht in wat normal is. Psychiaters praten over denk-, stemmings- of bewustzijnsstoornissen zonder voldoende inzicht in wat we ons moeten voorstellen bij normale humane denkprocessen, normale stemming of normaal bewustzijn.

Naturarlik kan men wat dit betreft de dorst lessen door het lezen van velle voortreffelijke beschrijvingen in de schone letteren. I $k$ acht dit zelfs zo belangrijk dat ik meen dat dit een noodzakelijk onderdeel moet uitmaken van de psychiatrische opleiding. Maar het zall duidelijk zijn dat ook de verruk kelijkste picturale weergave van een menselijk naakt nog iets anders is dan wetenschappelijke anatomie. En omgekeerd natuurlijk. Overigens zou ik willen opmerken dat ten aanzien van het menselijk functioneren de scherpe pen tot meer indringende ontleding in slat lijkt dan het zachte penseel.

Voor een wetenschappelijk verantwoorde psychiatrie blijft er een grote behoefte bestaan aan relevante, dat wil zeggen naar de psychopathologie toegesneden, gegevens en theorieén over het normale psychisch funtioneren. Nodig hiervoor is een echte klinische psychofysiologie. Mij dunki dat deze discipline zo naw (en zo gauw) mogelijk betrokken dient te worden bij het dagelijks functioneren van een psychiatrische universiteitskliniek. De neuropsychologie en - een stap verder - de neurofysiologie vormen de natuurlijke brug naar de neurologie. De toetreding van de neuropsycholoog Prof. Jolles en zijn staf tot de Kapaciteitsgroep K linische Psychiatrie wordt door mij dan ook met vreugde begroet.

Met neurofysiologie bedoel ik hier overigens niet hetzelfde handwerk (hoe nuttig overigens ook) als gemeenijk wordt beoefend in de betreffende $\mathrm{KNE}$-afdelingen van de diverse ziekenhuizen. $1 \mathrm{k}$ bedoel een discipline die zich theoretisch en daadwerkelijk bezighoudt met het functioneren van menselijke hersenen in relatie tot menselijk 
gedrag.

Indien ieder van deze functionarissen zich de moeite zou willen getroosten om een grondig onderzoek te doen naar wat in de schatkamers van eigen huis aan relevante kennis aanwezig is, zou naar mijn mening reeds nu veel toepasbaar materiaal op tafel komen. Mijns inziens zou voor de coördinatie van al deze gegevens de hulp van een informatica deskundige van grote betekenis kunnen zijn. Hersenen kunnen (in een bewust reductionistisch model) in principe opgevat worden als een informatie verwerkend orgaan en gedrag kan gezien worden als de "output" van dit systeem. Het is hier niet de plaats daar verder op in te gaan.

\section{NEURO-PSYCHIATRISCH ONDERZOEK}

Uiteraard met inachineming van alle ethische gedragsregels dient klinisch psychiatrisch onderzoek daar te gebeuren waar de patienten en de middelen zijn. Door de mogelijkheid van samenwerking met de neurologen en andere somatische specialisten, de aa nwezigheid var uitgebreide laboratorium faciliteiten, de nabijheid van preklinische specialisten en laboratoria is de klinisch psychiatrische afdeling van een (academisch) ziekenhuis een voor de hand liggende plaats waar dit deel van het psychiatrisch onderzoek op wruchtbare wijze kan gebeuren. Ten aanzien van de ethische aspecten will ik daarbij nog opmerken dat eenieder die (terecht) vindt dat hij of zij recht heeft op de best mogelijke gezondheidszorg, dit recht ook moet erkennen voor zijn of haar kinderen. Dat wil zeggen dat niet meewerken aan onderwijs en onderzoek, uiteraard weer met inachtneming van de daarbij geldende et hische regels, op zich zelf een onethisch standpunt vertegen woordigt. Mijn ervaring toont telkens weer aan, dat patienten over het algemeen deze opvatting deten en zelfs bereid zijn tot enthousiaste medewerking mits er voldoende samenhorigheid, openheid en uitleg voorhanden is. Voorwaarde is daarbij dat de hele staf, met name ook de verpleging ntet alleen dit standpunt deelt maar ook actief en volwardig betrokken is bijdeze onderwijs-en onderzoektaken. 
Ten aanzien van medisch wetenschappelijk onderzoek blijken niet alleen in de maatschappij, vooral door Hunne Majesteit de Media vertegenwoordigd, maar ook bij allerlei "deskundige" instanties, binnen en buiten de geneeskunde zeer irrationele, emotionele vooroordelen een merkwardige rol te spelen. Als voorbeeld will ik noemen onderzoek naar stoormissen van het hart in vergelijking met onderzoek naar afwijkingen van hersenenen gedrag. Het hart is de warm kloppende bron van alle leven. Hier zetelen alle romantische gevoelens en de Liefde zelf. Dit alles bereikt zijn hoogste vervulling in de verering van Het Heilig Hart. In "de nacht van het hart" worden vele miljoenen van hun slaap en evenzovele guldens beroofd voor onderzoek en behandeling van dit boven alles geliefde orgaan. Hart-ren-wagens staan klaar om U bij het eerste alarm vliegensvlug te brengen naar met vele deskundigen en de nieuwste apparatur gestoffeerde hartbewakingsafdelingen. Luchtbruggen naar alle delen van de wereld worden gefinancierd in af wachting van een eigen hartchirurgie.

Hoe pover steekt hierbij af de assepoester van alle organen: het brein. De werking daarvan kan men zich niet goed voorstellen. Dat is dus geheimzinnig en daardoor angstaanjagend. Intelligentie geeft macht, die vaak op ondemocratische manier wordt misbruikt. "Hoe groter geest, hoe groter beest". De gedachte aan onderzoek. laat staan ingrepen in dit orgaan vervult eenieder met grote huiver. Geen nacht van het brein. Hoogstens gooiden actiegroepen's nachts de ruiten in van wit zich wagde aan biologisch psychiatrisch onderzoek. Men wil geen monster van Frankenstein en alles wat zich bezig houdt met dit soort onderzoek wordt al gauw gecontamineerd met gedachten aan concentratiekamppraktijken.

Het hart is nader dan het brein. Dat geldt woor de hele gemeenschap en de media, maar ook voor bestuurders van ziekenhuizen en voor overheden die ziekenhuisbedden en researchgelden verdelen. Deze atavistische vooroordelen spelen helaas een rol in de partnerrelatic van ziekenhuispsychiatrie en haar thuisbasis het ziekenhuis. Het wordt tijd dat deze emoties ter sprake en tot een oplossing komen. Tot zolang hopen we toch op een verstandshuwelijk. 
ledere dokter, die ervaring heeft in de gezondheidszorg, weet dat zijn patiënten niet alleen fysisch-biologische objecten zijn. Hoe beter hij zijn beroep begrijpt, des te meer zal hij rekening houden met psychologische en sociale aspecten van zijn patiënten. Ik zeg dit uitdrukkelijk om duidelijk te maken dat niet alleen psychiaters dit monopolie voor zich kunnen claimen.

Het eigene bestaat vooral daarin dat het systernatisch bestuderen en toepassen van de gedragswetenschappen ten dienste van diagnose en therapie, als aanvulling van zijn medische kennis, tot de wezenlijke bestanddelen van zijn specialistische bagage horen.

De nog relatief jonge wetenschappen als psychologie en sociologie hebben in de laatste decennia nieuwe dimensies toegevoegd aan de psychiatrie.

Daarmee heeft dit specialisme het nogal eens moeilijk. Zo moeilijk dat het in oraties als deze haast onmogelijk lijkt voorbij te gaan aan de uitspraak van Professor H.C. Rümke, die zich in "een bloeiende psychiatrie in gevaar (1954)" met de grootste bezorgdheid afvraagt "is de psychiatrie buiten haar oevers getreden, overstroomt zij gebieden waar zij niet behoort, terwijl haar eigen domein langzaam maar zeker droog komt te liggen?"

Een dergelijke uitbreiding van een specialisme moet inderdaad als een "tour de force" gezien worden. Iedere arts-assistent in opleiding en naar ik meen ook iedere medisch student, die geconfronteerd wordt met de psychiatrie, dreigt voortdurend het spoor bijster te raken. Zo is het in ieder geval ook mij vergaan.

Integratie van alle relevante medische, psychologische en sociale gegevens, wordt daarbij nog aanzienlijk bemoeilijkt door de complexiteit en de relatieve onbekendheid met bouw en functies van dat moeilijke orgaan, de hersenen en de relatieve onrijpheid van de jonge gedragswetenschappen. Toch is het onverdraaglijk om als psychiater te functioneren zonder een alles integrerend model. Sommigen komen ertoe hun toevlucht te nemen tot een vaak enigszins modieus gekleurde, biologische, psychologische of sociale eenzijdigheid. De daarmee samenhangende, innerlijke onzekerheid leidt soms tot orthodoxe verkettering van andere standpuntem.

Zonder de suggesties te wekken van hiervoor "de" 
oplossing te bieden heb ik voor mij zelf de hoop dat de nieuwe wetenschap van de informatica ons kan helpen een oplossing, in de vorm van een integrerend model, te vinden. Ik heb dat hierboven al gezegd. Tot zolang heb ik mij neergelegd bijeen "onmachtsmodel" waarmeeik kan leven door in een team van goede stafmedewerkers deze onmacht samen te delen.

\section{LIA ESONPS Y CHIATRIE}

Vooral door de toevoeging van systematisch bestudeerde en in het medisch denken en handelen geïtegreerde, methodisch toegepaste gedragswetenschappen kan de psychiatrie in het kader van de liaesonpsychiatrie "iets terug doen", iets wezenlijks bijdragen aan de niet psychiatrische specialismen.

Nogmaals, vele jaren erwaring in een algemeen ziekenhuis hebben mij duidelijk gemaakt dat ook de $2 \mathrm{~g}$. orgaanspecialisten niet de robotachtige technocraten zijn die hun patienten alleen als "casus" observeren en behandelen. Door hun grote menselijke ervaring met lijden, pijn en naderende dood weten zij vaak meer van menselijke emoties en hoe patiënten afhankelijk zijn wan hun sociale omgeving, dan menig gek wallificeerde hulpverlener. De typische bijdrage van de psychiater is echter zijn specialistische deskundigheid in de gedragswetenschappen, die hij weet te integreren in zijn medische kennis. Zijn visie is daarom principieel niet dualistisch. Het traditionele onderscheid tussen somatische patiënten, "de echte zieken" en de anderen met "functionele klachten" is dualistisch en verwerpelijk.

Gemaskeerde, dus niet gediagnostiseerde psychologische of psychiatrische problemen kunnen de diagnose en behandeling van "somatisch zieken" ernstig compliceren. Ze verlengen de opnameduur, nodigen uit tot dure en hisicuragenu" ondercuekingen. Kortom, ze maken de geneeskunde duurder en dreigen soms de arts-patiënt relatie te verstoren.

Omgekeerd kan de psychiater zijn collegae en hun patienten behoeden voor een andere, niet zeldzame en ewen nadelige procedure: de psychiatrische diagnose "per exclusionem". Men kan niets vinden, dus moet het psychisch zujjn.

Klachten zijn alleen "psychisch" alls er na uitvoerig en zorgvuldig onderzoek cen begrijpelijke samen hang gevon- 
den wordt tussen de klachten en de psychiatrische bewindingen. Er moet een duidelijk psychiatrische diagnose zijn die de klachten kan verklaren.

In dit verband is het ook van belang vast te stellen, waar de grens ligi tussen wat tot de echte deskundigheid hoort van de psychiater, de psychopathologie, en het immens uitgebreide gebied van psycho-sociale problemen, die horen tot het normale menselijke bestaan. Juist in het algemeen ziekenhuis vindt men een concentratie van deze problemen. Problemen rond ziekte, lijden en dood. Zo is normaal menselijk stervensgedrag natuurlijk geen psychiatrie. Het is zelfs navrant iets dergelijks te stellen, maar de ervaring leert dat het gevaar van verwisseling dreigt.

\section{"STA FGERICHTE LIA ESONPS YCHIATRIE"}

Dit laatste brengt ons tot een onderscheiding die vooral in de literatuur wordt aangebracht. Daar leest men over patiëntgerichte en stafgerichte liaesonpsychiatrie. Ik neem aan, dat de schrijvers met dit laatste niets naars bedoelen, maar mijns inziens is "stafgerichte psychiatrie" een ongelukkige uitdrukking, die hier en daar dan ook met de nodige reserve en begrijpelijke irritatie wordt beluisterd. Bedoeld wordt de hulp, die vanuit de psychiatrische afdeling, op verzoek aan een niet psychiatrische afdeling van het ziekenhuis wordt gegeven, waardoor deze afdeling beter in staat is om met bepaalde gedragsproblemen van hun patiënten om te gaan.

Eigenlijk gaat het hier om een geleidelijk werlopend, methodisch proces, dat op de duur leidt tot een cultuurverandering. Omdat de "cultuur" van een afdeling in het algemeen ziekenhuis vooral door de verpleging wordt gedragen, zeker in een academisch ziekenhuis met meer "afstandelijke" chefs en wisselende assistenten, zal deze vorm van liaesonhulp op de eerste plaats moeten bestaan uit een methodische interactie op verpleegkundig niveau. Dat wil dus zeggen dat laesonpsychiatrie een interactie veronderstelt tussen de diverse afdelingen wan het ziekenhuis en de gehele staf van de psychiatrische afdeling met het accent op de verpleging. Een dergelijke interactie komt slechts tot stand, wanneer deze psychiatrische afdelingeen wezenlijk onderdeel is van het ziekenhuis en door alle medewerkers ook herkend wordt als "een van ons". Overigens is dit slechts één van de argumenten voor een eigen, inpandige psychiatrische afdeling in thet zieken- 

bij, door scherpere indicatiestelling en meer ambulante mogelikheden, de opnametijden korter worden, is slechts toe te juichen. ook al omdat hierdoor steeds duidelijker wordt waarom en wanneer een opname in de psychatrische ziekenhuisafdeling echt nodig is. Vooral nuer steeds meer stemmen opgaan om de "klinische psychiatrie" weer in de richting van het algemeen ziekenhwis te laten bewegen is het zaak deze klinische taken zo scherp mogelijk, operationeel in termen van gezondheidszorg, onderwijs en research, te definieren. Een dergelijke operationele definitie zou de volgende elementen kunnen omvatten:

- de opnameduur zal beperkt zijn.

- de diagnostiek en behandeling zullen wezenlijk integraal zijn, d.w.z. dat alle somatische, psychologische en sociale aspecten volledig en gelijkelijk in het proces betrokken rijn,

- men zal zoveel mogelijk gebruik maken van gestandaardiseerde en geprotocolleerde diagnostische en therapentische methoden,

- er dienen effectieve relaties te bestaan met de andere afdelingen van het ziekenhuis en de praeklinische vakgebieden alsook met de andere operationele terreinen wan de geestelijke gezondheidszorg.

- deze afdeling zal speciale aandacht en woorzieningen moeten hebben voor de psychogeriatrie.

- deze kenmerken hebben niet alleen betrekking op de gezondheidszorg, maar ook op de daarop gebaseerde opleidings-, onderwijs-en onderzoektaken.

De psychiatrie van het algemene ziekenhwis zal op de geschetste manier steeds meer samenvloeien met het operationeel bepaalde begrip klinische psychiatrie, een effectief en heilzaam instrument binnen het geheel van psychiatrische en medische voorzieningen. Een werkterrein ook dat zich bij witstek leent voor onderwijs en onderzoek.

Klinische psychiatrie is geen vreemde eend meer, wet een andere eend, die op een naturlijke manier haar plats vindt tussen de andere bewoners van de bijt, een nuttige en betrouwbare partner voor de "geachte collegae" waarmee zij de voordew wan het ziekenhuis deell.

Daaraan gestalte te geven, samen met allen, die reeds mu op dit terrein in het Academisch Ziekenhuis Maastricht, 
de Medische Faculteit en in de diverse instituten van intra-en extramurale geestelijke gezondheidszorg werkzaam zijn, beschouw ik als de centrale opgave van mijn benoeming.

U, Professor Richartz, alle leden van de Kapaciteitsgroep Klinische Psychiatrie en allen, die aan mijn benoeming hebben bijgedragen zeg ik gaarne dank voor het in mij gestelde vertrouwen. 
Geraadpleegde literatuur:

Cornips, J., Bijdrage tot de geschiedenis van de krankzinnigenzorg te Maastricht, Het Burgerlijk Armbestuur te Maastricht in samenwerking met het Sociaal Historisch Centrum voor Limburg, 1952.

Cornelis Winkler, Herinneringen, Bohn, Scheltema, en Holkema, Utrecht-Antwerpen, $\mathbf{1 9 8 2}$.

López-lbor.j., J.J., e.a.. General Hospital Psychiatry, Exerpta Medica, Amsterdam-Oxford-Princeton, 1983.

van Eck, L.A.J.M. Gersons, B.P.R., Jongerius, P.J. Kuilman, M. Spanningsvelden in de psychiatrie, Boom, 1985.

Schmidh, F.J.M. Die Entwicklung der Irrenpflege in den Niederlanden. Vom Tollhaus bis zur gesetzlich anerkannten Irrenanstalt, Verlag Murken-Altrogge, Herzogenrath, 1985.

Schudet W.J., "Wat mankeert de psychiatrie"?", Oratie, Erasmus Universiteit, Rotterdam, 1985. 